\title{
Soil Characteristics of Natural Silver Linden (Tilia tomentosa Moench) Populations
}

\begin{abstract}
Salih Parlak, ${ }^{*}$ and Erdem Tetik
Studies regarding the determination of the ecological characteristics of the natural distribution areas of the silver linden (Tilia tomentosa Moench) are limited. It is of great importance to select areas with similar natural cultivation characteristics in the plantations established for flower or timber production. Physiographical factors affecting these forests were explored to determine the physical and chemical characteristics of the soil. The soil samples were collected from three natural populations, and a total of 43 samples were examined in terms of aspect, elevation, declivity position, and slope. It was determined that the natural linden populations expanded between the altitudes of $0 \mathrm{~m}$ and $400 \mathrm{~m}$ and $88 \%$ of the populations were denser in aspects with shadow. It was found that $91 \%$ of the soil was in the class of "deep to very deep", $61 \%$ showed an expansion in sandy clay loam soils, and $30 \%$ showed an expansion in sandy loam soils. Average soil $\mathrm{pH}$ ranged between 5.6 and 6.6. The soils were found to be salt-free and slightly limy. In terms of the organic carbon amount, the soils were classified as medium.
\end{abstract}

Keywords: Tilia tomentosa; Silver linden; Natural expansion; Soil characteristics

Contact information: Bursa Technical University, Faculty of Forestry, Department of Forest Engineering, 16310, Bursa, Turkey; *Corresponding author: salih.parlak@btu.edu.tr

\section{INTRODUCTION}

Turkey is comprised of three different plant regions, namely the Mediterranean, Europe-Siberia, and Irano-Turanian. Each one of these regions has its own endemic species and natural ecosystems (Tan 2010). In terms of the variety of species, Turkey has 11,446 natural and 3649 endemic species (Güner et al. 2012). The linden (Tilia sp.), which is native to the Northern Hemisphere, consists of 30 different species. Four different linden species, namely $T$. rubra subsp. caucasica, $T$. cordata, $T$. platyphyllos, and $T$. tomentosa are found in Turkey, and the distribution area of these four species is 12.574 hectares (General Directorate of Forestry (OGM) 2013; Oral 2018). Linden constitutes approximately $0.06 \%$ of Turkey's forest area with the majority of it consisting of $T$. tomentosa Moench (Davis 1967; Korkut 2011). T. tomentosa is the most common species and is the most known in Turkey (Davis 1967). In addition, T. tomentosa is generally found in regions such as Bosnia and Herzegovina, Croatia, Macedonia, Montenegro, Serbia, Slovenia, Bulgaria, Romania, Greece, Turkey, and in parts of China (Mauer and Tabel 1995; Blumenthal et al. 1998). T. tomentosa has three different ecotypes based on altitude elevation (Kalmukov 1994). The flowers of $T$. tomentosa consist of five petals of yellowish-white color and have an unusually strong smell, which is specific to the flower itself. It is also used as an ornamental plant in parks and gardens in various cities (Uslu 2004; Xie 2018). T. tomentosa's bark is smooth and grey, while its leaves are heart-shaped and covered with white tomentum, especially on the underneath in contrast to the leaves of Tilia cordata and T. platyphyllos, which are hairless. The flowers are collected in full 
bloom, dried, and preserved under low-moisture conditions. Since the middle ages, the linden flowers have been used as a diaphoretic to promote perspiration. In addition, the flowers were traditionally used as tranquilizers and to treat headaches, indigestion, and diarrhea. The infusion of the flowers makes a pleasant-tasting tea. Traditionally linden flowers were added to baths to quell hysteria and steeped as a tea to relieve anxiety-related indigestion, heart palpitation, and vomiting (Anonymous 2012). More than half of the production of linden is consumed as tea in winter, making great contributions to the relation between the forest and the public in the cities of Bursa and Yalova (Tuttu et al. 2017). According to the General Directorate of Forestry (OGM 2018), the average production of linden for the last 28 years has been 37 tons per year, while the average was 208 tons for 2017. Because the height of the silver linden can reach up to $40 \mathrm{~m}$ (Uslu 2004), the flower harvesting is conducted by cutting the thick branches, which in turn heavily damages the tree itself. For this reason, it is suggested to improve the linden's natural distribution areas (Eltan 2012). Thus, it is of great importance to take the linden as cultivar to decrease the damage to the tree and to establish timber plantations to benefit from the flowers in areas in accordance with its ecology. Therefore, it is necessary to determine the cultivation environment of the natural populations and the soil characteristics of the areas. However, the scientific studies conducted in this area are limited. In this study, the soil characteristics of the natural populations of T. tomentosa in the Bursa Regional Directorate of Forestry were determined and scientific data were collected for the forestations and the establishment of the plantations.

\section{EXPERIMENTAL}

\section{Materials}

Introduction of the study area

The material of this study consisted of the pure or mixed T. tomentosa forests that have naturally spread in Gökçeören (Bursa), Yeniköy (Bursa), and Esenköy (Yalova), all located in Turkey. The samples were collected in these three regions (Fig. 1).

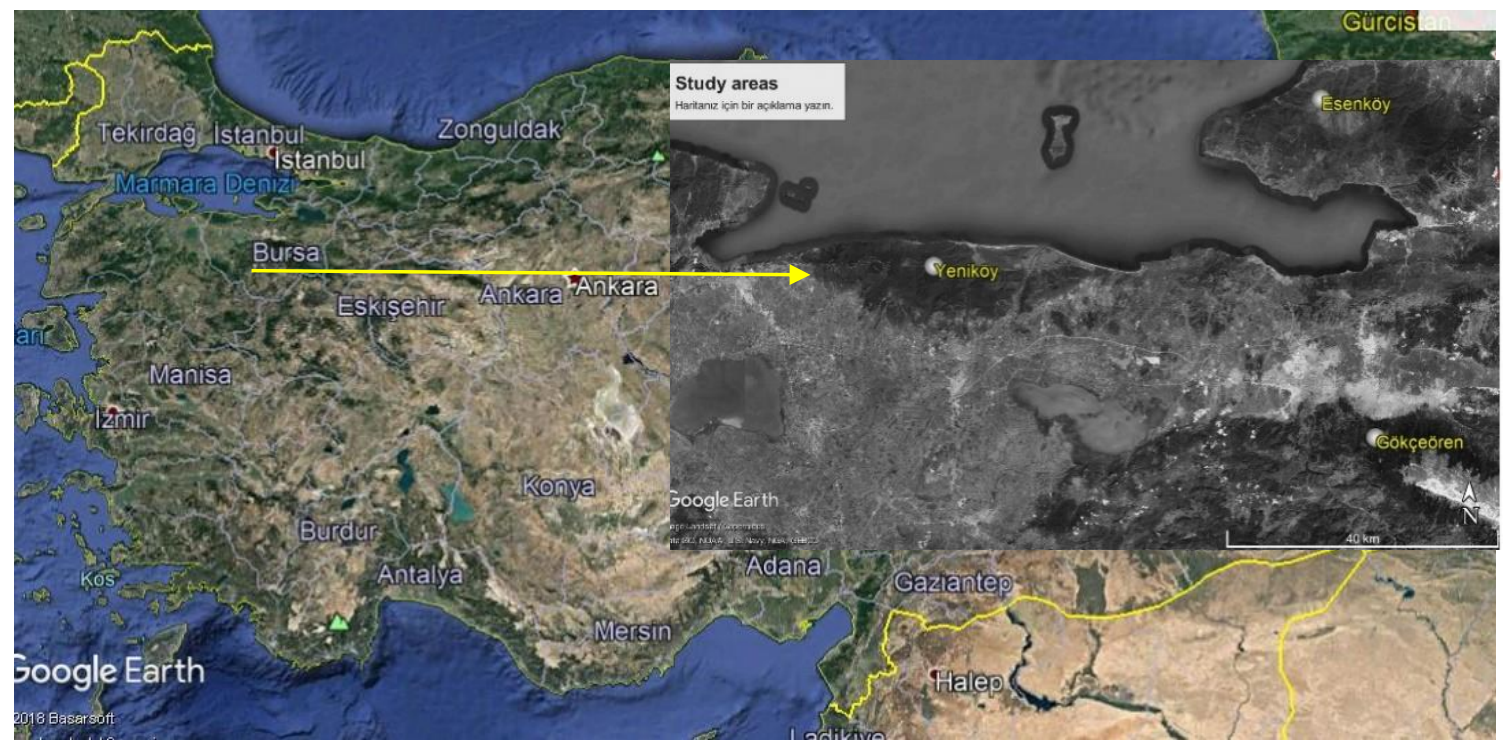

Fig. 1. Geographical position of the study area 
A total of 43 soil holes were dug and 90 samples were collected considering the horizon boundaries. Shovels, pickaxes, garden trowels, polyethylene bags, tape measurers, GPSs (Garmin Ltd., Olathe, KS, USA), and camera (Nikon D 3100; Nikon, Tokyo, Japan) were used to obtain the sample data.

\section{Methods}

Extraction and analyses of the samples and assessment of the climatic data

The holes in the soil were dug in the regions of the study area. In pedological field studies, the horizon is the basic sampling unit. Therefore soil samples were taken according to the horizon boundaries. In this study a total of 90 samples were investigated; 43 samples were obtained at 0 to $20 \mathrm{~cm}$ depth, 29 samples were obtained at 21 to $70 \mathrm{~cm}$ depth, and 18 samples were obtained at 71 to $120 \mathrm{~cm}$ depth. Approximately $1 \mathrm{~kg}$ of soil was collected in polyethylene bags for the samples in consideration with the color difference in the horizons. The absolute and physiological depths of the soil, thickness of the soil horizon, mother rock structure, profile, and surface rocky structure, ground water, and staining status with drainage (Karaöz 1989) were taken note. Using the samples taken from the areas with linden populations, stand parameters, such as closeness, mixture, stand health, and the status of benefit, were determined. Great importance was set on digging the holes in areas where pure T. tomentosa are situated. Topography, field position, aspect, elevation, declivity slope, and the coordinates of the areas were measured and recorded on inventory cards to determine the physiographical characteristics of the soil areas. Each soil sample was labelled with the sample's profile number and data before being brought to the lab. The aspect assessments were conducted using the ArcCIS program (ESRI, version 10.5, Redlands, CA, USA) on four main directions. The areas from which the samples were taken were considered in the determination of the slope.

A total of 90 soil samples were brought to the lab and stored in pans until they were air-dried for two months. The samples were then ground in a mortar and sieved with a 2$\mathrm{mm}$ sieve. The thin part of the soil was used in the physical and chemical analyses $(0<2$ mm) (Karaöz 1989). Sand-silt-clay composition of the soil samples were determined according to the hydrometer method (Kroetsch and Wang 2008). The $\mathrm{pH}$, salt, and electrical conductivity (EC) were determined (Richards 1954; Tüzüner 1990). The calcium content was determined based on total $\mathrm{CaCO}_{3}$ content (Çağlar 1949; Tüzüner 1990) using a Schiebler calcimeter (Eijkelkamp Soil \& Water, Giesbeek, Netherlands), and organic carbon content was determined following the Walkley-Black wet burning method (Tüzüner 1990). The contents of total nitrogen (N) (Bremner 1965), plant available phosphorous (P), and available potassium $\left(\mathrm{K}_{2} \mathrm{O}\right)$ were determined using a Perkin Elmer- Inductively Coupled Plasma Optical Emission Spectroscopy (ICP OES) instrument (Optima 7000 DV; Perkin Elmer, Waltham, MA, USA), as shown by Tüzüner (1990).

Slope and aspect were determined based on the obtained data (Ürgenç and Çepel 2001). Soil type was analyzed by the method of International Soil Classification Triangle (Çepel 1960; Atalay 2006). Profile rockiness, surface rockiness, soil depth (Kantarc1 1987), organic carbon amounts (Jackson 1962), calcium contents (Çağlar 1949; Evliya 1964), saltiness (Bernstein 1970; Verhoeven 1980), and pH were also determined (Saatç1 et al. 1983; Kantarc1 2000).

The data obtained from the meteorology stations of Bursa and Yalova, which were the closest ones to the study areas, were used for the determination of climatic characteristics. The climatic changes and climatic types in the study area were examined according to the Thornthwaite method (Thornthwaite 1948) by using the average 
precipitation and average temperature values. During the interpolation of the meteorology station data to the study area, the temperature values were decreased $0.5^{\circ} \mathrm{C}$ per $100 \mathrm{~m}$ and the precipitation values were increased $54 \mathrm{~mm}$ per $100 \mathrm{~m}$ (Çepel 1988a; Özyuvac1 1999).

\section{RESULTS AND DISCUSSION}

\section{Climatologic Findings}

According to the meteorological data obtained from the meteorology station of Bursa, the average annual temperature in the study area was $14.6{ }^{\circ} \mathrm{C}$ between the years 1926 to 2016, and the annual precipitation average was $707.5 \mathrm{~mm}$. The average annual temperature for the Yalova area between the same years was $14.7{ }^{\circ} \mathrm{C}$, and annual precipitation average was $749.8 \mathrm{~mm}$. According to the findings obtained with the Thorntwaite method (Thornthwaite 1948), Bursa was humid, had medium temperature (mesothermal), was a city in which water deficiency occurred in the summer, and had a climatic type close to an oceanic climate. In contrast, theYalova area was semihumid, had medium temperature (mesothermal), was a city in which water deficiency also occurred in the summer, and had a climatic type close to an oceanic climate.

\section{Floristic Structure}

Other species that were present in the study area along with linden were as follows: Castanea sativa Mill., Quercus cerris L., Quercus petraea (Mattuschka) Lieb., Corylus avellana L., Laurus nobilis L., Daphne pontica L., Hedera helix L., Alnus glutinosa L. Gaertn, Styrax officinalis L., Rubus ssp., Erica ssp., Arbutus andrachne L., Cistus salviifolius L., C. laurifolius L., Sorbus torminalis L. Crantz, Rhus coriaria L., Platanus orientalis L., Populus tremula L., Carpinus betulus L., Fraxinus ornus L., F. angustifolia Vahl., Rosa canina L., Cornus mas L., Corylus avellana L., Diospyros lotus L., and Acer campestre L. In addition to these species, in studies conducted by Özel et al. (2017) and Stanescu et al. (1997), it was stated that Euphorbia amygdaloides L., Helleborus orientalis Lam., Primula vulgaris Huds., Rubus hirtus Waldst. \& Kit, Ruscus aculeatus L., Ruscus hypoglossum L., Smilax aspera L., Smilax excelsa L., and Viola sieheana W. Becker were present.

It was found that the Tilia tomentosa were sucessfully mixed with $Q$. cerris and $Q$. petraea. It was also determined that Castanea sativa, Platanus orientalis, and Alnus glutinosa generates a successful mix at high humidity regions. The Erica spp, Arbutus andrachne, Cistus spp, and Rubus that are located at south slopes also create succesful mixtures. Once the road-side samples were investigated, it was observed that the successful mix was obtained with Smilax spp, Rubus hirtus, Rhus coriaria, Populus tremula, Cornus mas, Corylus avellana. In the scattered regions Acer campestre, Sorbus torminalis, Carpinus betulus, Diospyros lotus generated successful mix. Laurus nobilis, Hedera helix, Ruscus spp, Smilax spp created successful mix in the Linden stands' under canopy cover.

\section{Physiographical Characteristics}

Elevation from sea level

The soil samples collected from the natural linden population areas in Esenköy and Yeniköy were located between $60 \mathrm{~m}$ to $350 \mathrm{~m}$ altitude, and the highest altitude reached was measured as $450 \mathrm{~m}$ and the average altitude was measured as $266 \mathrm{~m}$. It was determined that $68 \%$ of the 10554 ha natural expansion area was located between 0 to $400 \mathrm{~m}, 32 \%$ was 
between $401 \mathrm{~m}$ to $800 \mathrm{~m}$, and $0.4 \%$ was above $800 \mathrm{~m}$. In a study conducted by Özel et al. (2017), it was also stated that the linden expansion in the same area could rise mostly up to $400 \mathrm{~m}$. It has been cited (Davis 1967) that the expansion areas of T. tomentosa were between $50 \mathrm{~m}$ to $400 \mathrm{~m}$. It was also specified by Şahin et al. (2018) that natural linden population areas could rise up to $1000 \mathrm{~m}$ in the Marmara region, but the optimal expansion area was between $50 \mathrm{~m}$ to $650 \mathrm{~m}$. It was stated that these areas could rise up to $1000 \mathrm{~m}$ in Romania (Radoglou et al. 2009), but the best development occurred in $150 \mathrm{~m}$ to $450 \mathrm{~m}$ (Haralamb 1967; Stanescu et al. 1997), which shows that the literature is in accordance with the present study.

\section{Aspect-slope}

The majority of the linden populations in the study area were more dense in the northern and western aspects. Approximately $7 \%$ of the soil samples were taken from the eastern aspect, $23 \%$ of them were taken from the western aspect, $65 \%$ of them were taken from the northern aspect, and 5\% of them were taken from the southern aspect. According to the aspect analysis conducted with the ARC-GIS program, $88 \%$ of the populations were more dense in the western and northern aspects, which generally were subject to more precipitation, andwere cooler and more humid (Dirik 2008; Akkemik 2018). Previous studies also support the findings of the present study. For example, in a study conducted by Özel et al. (2017), it was determined that $69 \%$ of $T$. tomentosa populations were located in areas that receive shade. According to Öner (2009) and Öner and Akbin (2010), the T. Tomentosa populations in the Kapıdağ Peninsula were more dominant in declivities with northern aspects and expanded as much as they could in these areas. It was stated by Aksoy (2006) that $T$. tomentosa populations showed expansion in northern, northeastern, northwestern, and southwestern aspects.

The slope in the sampling areas changed between $20 \%$ to $40 \%$ and the average slope was $32 \%$. When the populations showing expansion within the Regional Directorate were classified according to slope groups, $4 \%$ of them were classified as medium slope surfaces (slope between $10 \%$ to $20 \%$ ), $52 \%$ of them were classified as high slope surfaces (slope between $20 \%$ to $50 \%$ ), and $37 \%$ of them were classified as very high slope surfaces (slope between 50\% to 100\%). Surfaces with a slope close to steep and with > 100\% slope were only 2\% (Elibüyük and Y1lmaz 2010). No difference was observed among the populations in terms of slope. In the study conducted by Özel et al. (2017), while minimum slope was determined as $20 \%$, maximum slope was determined as $100 \%$. Approximately $15 \%$ of the areas were classed as steeply inclined hillsides, $23 \%$ of them were classed as steep fields, and it was also determined that the linden populations were in the fields with moderately inclined and above the inclined area. These findings (Şahin et al. 2018) also indicated that expansion was present in very slopy, steep, and very steep fields.

\section{Physical Characteristics of the Soil Soil type}

Two main soil types were identified in the study area: sandy clayed loam at $61 \%$ and sandy loam at $30 \%$. In addition, the loamy sandy soil at $7 \%$ and sandy clayed soil at $2 \%$ were also determined. It was specified by Atalay (2006) that the soil type of the horizon $\mathrm{B}$ in Yenikoy beech forests was sandy loam. When classified by Çepel (1988b), 91\% of the soils were medium-level fine-grained soil, $7 \%$ were coarse-grained soil, and $2 \%$ were fine-grained soil. Özel et al. (2017) showed that $T$. tomentosa populations in the Karadağ area showed expansion in loam soil at $61 \%$ and sandy loam soil at $15 \%$. It was expressed 
by Radoglou et al. (2009) that the T. tomentosa in Europe showed expansion in the sandy loam soil and loamy clay soil, and developed best in the loam, sandy loam, and clayed loam soils. They do not show any development in soils with heavy clay that limit root expansion. It was also emphasized by Kalmukov (1984) and Jaworski (1995) that they conducted their optimal expansion in sandy loam and loamy sandy soils. Additionally, in the study by Şahin et al. (2018) it was found that they showed expansion mostly in loam, sandy loam, and clayed loam soils.

It was found that the Yenikoy, Esenkoy, and Bursa areas were different from one another in terms of soil texture (Table 1). No statistically (SPSS Inc., v.15.0, Chicago, IL, USA) meaningful difference could be found among the populations in terms of sand ratios. The silt ratios of the samples taken from Bursa were lower than those of the other populations. While the clay ratios were the same in the Bursa and Esenköy regions, they were lower in the Yeniköy region. Data similar to those of the study conducted by Özel et al. (2017) were attained in terms of soil type. No difference was found in the ratios of sandsilt-clay according to the depth stages.

Table 1. Texture, Organic Carbon, $\mathrm{pH}$, and Salt Values According to the Plant Populations

\begin{tabular}{|c|c|c|c|c|c|c|c|}
\hline Location & $\begin{array}{c}\text { Sample } \\
\text { No. }\end{array}$ & $\begin{array}{c}\text { Sand } \\
(\%)\end{array}$ & Silt (\%) & Clay (\%) & $\begin{array}{c}\text { Organic } \\
\text { Carbon } \\
(\%)\end{array}$ & $\mathbf{p H}$ & Salt (\%) \\
\hline Yenikoy & 27 & $\begin{array}{c}68.61 \\
\pm\end{array}$ & $\begin{array}{c}16.2 \pm \\
6.14 \mathbf{b}\end{array}$ & $\begin{array}{c}15.04 \pm \\
7.30 \mathbf{a}\end{array}$ & $\begin{array}{c}2.32 \pm \\
1.50 \mathbf{a}\end{array}$ & $\begin{array}{c}5.9 \pm \\
0.54 \mathbf{a}\end{array}$ & $0.006 \pm 0.003 \mathbf{b}$ \\
\hline Esenköy & 53 & $\begin{array}{c}64.10 \\
\pm\end{array}$ & $\begin{array}{c}14.84 \pm \\
6.62 \mathbf{a}\end{array}$ & $\begin{array}{c}21.06 \pm \\
6.80 \mathbf{b}\end{array}$ & $\begin{array}{c}2.06 \pm \\
1.12 \mathbf{a}\end{array}$ & $\begin{array}{c}5.8 \pm \\
0.52 \mathbf{a}\end{array}$ & $\begin{array}{c}0.0084 \pm \\
0.004 \mathbf{b}\end{array}$ \\
\hline Gökçeören & 11 & $\begin{array}{c}69.21 \\
\pm\end{array}$ & $\begin{array}{c}11.23 \pm \\
5.78 \mathbf{a}\end{array}$ & $\begin{array}{c}19.57 \pm \\
3.54 \mathbf{b}\end{array}$ & $\begin{array}{c}1.03 \pm \\
0.43 \mathbf{b}\end{array}$ & $\begin{array}{c}6.4 \pm \\
0.61 \mathbf{b}\end{array}$ & $\begin{array}{c}0.0031 \pm \\
0.006 \mathbf{a}\end{array}$ \\
\hline F-value & & 3.517 & 2.968 & 7.338 & 4.735 & 4.220 & 8.768 \\
\hline P-value & & 0.057 & 0.034 & 0.001 & 0.011 & 0.018 & 0.000 \\
\hline
\end{tabular}

Note: In each column and factor, values followed by the same letter are not significantly different $(P<0.05)$

\section{Soil depth and profile rockiness}

In the present study, it was determined that the absolute soil depth ranged between $55 \mathrm{~cm}$ to $150 \mathrm{~cm}$. When the absolute depths of the soils were classified according to Kantarc1 (1987), 9\% had medium depth, 37\% of them were deep, and 54\% of them were too deep. Too shallow and shallow soils were also encountered. In this respect, it can be said that $T$. tomentosa shows expansion mostly in deep and too deep soils. The absolute depths of the soil holes that were dug in the study area were $103 \mathrm{~cm}$ on average and it was seen that they were in the class of too deep soil (Kantarc1 1987). In the study conducted by Özel et al. (2017), 50\% of the soils were classed as medium deep and too deep.

The rockiness of the soil has important impacts in terms of water and food capacity. In this respect, when the soil rockiness was classified according to Kantarc1 (1987), 46\% of the sampling areas were little rocky, $40 \%$ were rocky, $7 \%$ were medium rocky, and $7 \%$ were too rocky. 'Too much rocky' and fully rocky soils were not found in the study area. Furthermore, in the study conducted by Özel et al.(2017), 31\% of the linden areas were determined as rocky, which is parallel to the findings of the present study. 
When an impermeable layer is observed in the soil, the water fills the pores of the soil and it moves horizontally depending on the slope of the impermeable layer or field (Kantarc1 2000), and high ground water affects the physiological depth (Birler 2009). Thus, groundwater examinations were also conducted in the holes dug. However, no staining was observed in any one of the holes depending on groundwater. This showed that the soils lost oxygen and keeping the groundwater in still status was not convenient for silver linden.

\section{Chemical Characteristics of the Soil}

Organic carbon, $\mathrm{pH}$, salt (EC), and calcium contents of the soil

The average $\mathrm{pH}$ value in natural $T$. tomentos $a$ forests were of mild acidic character with $\mathrm{pH}$ 5.96. While the measured minimum $\mathrm{pH}$ value was 5.11 , the $\mathrm{pH}$ was 8.02 only in one soil sample. It was stated by Atalay (2006) that the humid temperate of broadleaf forests are mostly the soils with acidic character. When the findings were assessed according to Kantarc1 (2000) and Erşahin et al. (2015), it was seen that there was no difference in terms of $\mathrm{pH}$ between the populations in the Yenikoy and Esenkoy regions, which had soils with medium-level acidic character. It was seen that the $\mathrm{pH}$ in the soil in the Bursa region was of a mild acidic characteristic, which was higher than the other two regions. As the soil depth increased, the $\mathrm{pH}$ value also increased and got close to neutral. According to Saatçı et al. (1983), while the average $\mathrm{pH}$ in 0 to $60 \mathrm{~cm}$ depth is 5.6 (mediumlevel acidic), $\mathrm{pH}$ in $60 \mathrm{~cm}$ to $120 \mathrm{~cm}$ stage was 6.6 with mild acid character (Table 1). In the study conducted by Özel et al. (2017) in Karadag, it was determined that $23 \%$ of the linden populations were in strongly acidic soil, $8 \%$ were in medium strong acidic soil, $38 \%$ were in mildly acidic, and $31 \%$ were in neutral reaction soils. While the minimum determined $\mathrm{pH}$ value was 5.2, a value of 7.9 was detected as the maximum value. In terms of the average soil $\mathrm{pH}$, the results of the present study and the results of the studies conducted by Özel et al. (2017) and Şahin et al. (2018) are close to one another. It was expressed by Radoglou et al. (2009) that $\mathrm{pH}$ in T. tomentosa populations in Europe was between 6.5 to 7.2 and the species showed expansion in the low acidic and neutral areas. Kalmukov (1984) stated that T. tomentosa prefers mild acidic or neutral soils ( $\mathrm{pH} 6.2$ to 7.2). In the study (Bilgin and Güzel 2017) conducted in Tilia rubra subsp. caucasica, it was determined that the $\mathrm{pH}$ ranged from 6.1 to 6.7 depending on the elevation.

The calcium content of the samples used based on the soil depths was determined as 2.6\% and classified as little limy soils (Çağlar 1949; Evliya 1964; Erşahin et al. 2015). In the study conducted by Şahin et al. (2018), the soil from $87 \%$ of the linden populations in Karadag area contained calcium at a medium level. It was asserted by Jaworski (1995) and Radoglou et al. (2009) that the species of Tilia in Europe generally prefer soil with high calcium content. There is no doubt that a single factor is not effective on the expansion of a plant species. However, it can be said that the Tilia tomentosa species in Turkey has shown development in the limeless mother rock and soil.

It was determined in this study that the soil samples taken from the silver linden populations increased in the salt-free class. In the study conducted by Özel et al. (2017), all of the soils were determined as salt-free. The difference among the populations in terms of the salt content was found statistically signifigant, and the salt amounts in the samples taken from the Bursa region were determined lower than the soil samples from other regions (Table 1). The reason for this could be the fact that salt condenses in the soil as a result of the evaporation of the sprinkles coming from the sea depending on the direction and speed of the wind (Gustafsson and Franzen 2000). Studies conducted by Reinap et al. (2012) have determined that the salt storage occurring near forests is 2 to 3 times more than 
those near beaches and $50 \%$ to $60 \%$ higher than in-forest salt storage. Different publications in this subject (Draaijers et al. 1988; Wuyts et al. 2008; Dmuchowski et al. 2013) support this hypothesis. It was observed in this study that there was no difference in the salt amounts depending on the depth stages.

Organic carbon content of the soil

In the present study, the average organic carbon ratio was $2.01 \%$. When the organic carbon amounts among the populations were compared, the organic carbon content in the samples taken from the Yenikoy and Esenkoy area were higher than those taken from the Bursa area. The organic carbon amounts of approximately $75 \%$ of the soils in the Bursa, Yenikoy, and Esenkoy regions were below 3\%, 25\%, and 2\%, respectively. In terms of soil quality, the desired organic carbon content is more than 3\% (Saltali 2014). As classified by Jackson (1962) and Gülçur (1974), the natural linden populations were located in medium class in terms of organic carbon content. According to Kantarc1 (2007) and Erşahin et al. (2015), 2.01\% were in soils with little organic carbon and poor in humus.

When assessed according to the depth stages, it was seen that the organic carbon contents decreased towards the lower layers in the soil samples. The average organic carbon ratio was $2.78 \%$ at 0 to $60 \mathrm{~cm}$ depth, $1.68 \%$ at $60 \mathrm{~cm}$ to $90 \mathrm{~cm}$ depth, and $0.83 \%$ at $90 \mathrm{~cm}$ to $120 \mathrm{~cm}$ depth (Özel et al. 2017). When the organic carbon contents of the soils of the sampling areas of this population were examined, it was determined that $8 \%$ of them had low levels of organic carbon, $15 \%$ in medium levels, and $77 \%$ in high levels of organic carbon contents.

Table 2. Correlation Analyses of Height, Slope and Some Additional Parameters

\begin{tabular}{|l|l|c|c|c|c|c|}
\hline \multicolumn{2}{|l|}{} & $\begin{array}{c}\text { Elevation } \\
(\mathbf{m})\end{array}$ & Slope (\%) & $\mathbf{p H}$ & $\mathbf{E C}$ & $\begin{array}{c}\text { Organic } \\
\text { Carbon }\end{array}$ \\
\hline Elevation (m) & Pearson Correlation & 1 & -0.135 & 0.032 & -0.061 & -0.122 \\
& Sig. (2-tailed) & & 0.202 & 0.762 & 0.566 & 0.251 \\
& $\mathrm{~N}$ & & 91 & 91 & 91 & 91 \\
\hline Slope (\%) & Pearson Correlation & & 1 & 0.067 & -0.117 & -0.047 \\
& Sig. (2-tailed) & & & 0.525 & 0.269 & 0.655 \\
& $\mathrm{~N}$ & & & 91 & 91 & 91 \\
\hline $\mathrm{pH}$ & Pearson Correlation & & & 1 & -0.142 & $-0.230^{*}$ \\
& Sig. (2-tailed) & & & & 0.178 & 0.028 \\
& $\mathrm{~N}$ & & & 91 & 91 \\
\hline EC & Pearson Correlation & & & & & $0.231^{*}$ \\
& Sig. (2-tailed) & & & & & 0.027 \\
& $\mathrm{~N}$ & & & & & 91 \\
\hline Organic & Pearson Correlation & & & & \\
Carbon & & & & & \\
& Sig. (2-tailed) & & & & \\
& $\mathrm{N}$ & & & & \\
\hline
\end{tabular}

${ }^{\star}$ Correlation is significant at the 0.05 level (2-tailed).

There were no correlation between the elevation and slope parameters and $\mathrm{pH}, \mathrm{EC}$ and organic carbon values. A negative correlation was found between the organic carbon values and $\mathrm{pH}$, whereas a positive correlation was found between organic carbon and EC. (Table 2). The increase in organic carbon amount produced decrease in $\mathrm{pH}$ values. The decrease can be explained with the slow decomposition of organic compounds in lower $\mathrm{pH}$ values (Kantarc1 2007; Leifeld et al. 2008). 


\section{CONCLUSIONS}

1. The physiographical and soil characteristics of silver linden (Tilia tomentosa Moench) populations that naturally expanded into the district of Bursa in Turkey were revealed. It was determined that silver linden populations expanded between the altitudes of $0 \mathrm{~m}$ and $400 \mathrm{~m}, 88 \%$ of them were in the aspects with shadow, and the average slope was $32 \%$. It was also seen that the linden populations showed more expansion in Esenköy and Yeniköy regions. Additionally, the humidity from the sea was had an effect in the formation of the pure sands. North-oriented winds blowing from the Marmara Sea provided a humid and cool climate in the northern aspects.

2. Approximately $91 \%$ of the soil was in the class of "deep to very deep" and $61 \%$ showed an expansion in sandy clay loam soils, while the other $30 \%$ showed an expansion in sandy loam soils. Approximately $91 \%$ of the soil was in the class of "deep to very deep". No indications were found that there was a problem resulting from the drainage maintenance. It was seen that $86 \%$ of the populations were in the class of "rocky to slightly rocky. It was also found that the soil $\mathrm{pH}$ of the natural silver linden populations changed from 5.6 to 6.6 and that the soils were in the class of medium acidic and mild acidic soils. In terms of saltiness, it was determined that the soils were in the class of the salt-free type. Average calcium content was $2.6 \%$ and belonged to the class of slightly limy nature.

3. The average organic carbon amount was $2.01 \%$ in the soil samples, and it was determined that the organic carbon amount decreased as the depth increased. In terms of the organic carbon amount, the soils studied were classified as medium.

\section{ACKNOWLEDGEMENTS}

This study was supported by the Scientific Research Projects Unit of Bursa Technical University (Project No. 171 L 23)

\section{REFERENCES CITED}

Akkemik, Ü. (2018). Türkiye’nin Doğal-Ekzotik Ă̆aç ve Çalıları [Natural-Exotic Trees and Shrubs of Turkey], Orman Genel Müdürlüğü Yayınları, Ankara, Turkey.

Aksoy, N. (2006). Elmacık Dă̆ı (Düzce) Vejetasyonu [Elmacık Mountain (Düzce) Vegetation], İstanbul Üniversitesi Fen Bilimleri Enstitüsü, İstanbul, Turkey.

Atalay, İ. (2006). Toprak Oluşumu, Sınıflandırılması ve Coğrafyası [Soil Formation, Classification and Geography], Meta Basımevi, Bornova, İzmir, Turkey.

Bernstein, L. (1970). Salt Tolerance of Plants (No. 283), USDA Agriculture Information Bulletins, Washington DC, USA.

Bilgin, A., and Güzel, Ş. (2017). "Foliar resorption and nutrient changes in leaves and soils of Tilia rubra Subsp. caucasica (Linden) along an altitudinal gradient during the growing season," Fresenius Environmental Bulletin 26(2a), 1607-1621.

Birler, A. S. (2009). Endüstriyel Orman Ağaçlandırmaları [Industrial Forest Afforestation], Duzce Üniversitesi Orman Fakültesi Yayınları, İstanbul, Turkey. 
Blumenthal, M., Busse, W. R., Goldberg, A., Gruenwald, J., Hall, T., Riggins, C. W., and Rister, R. S. (1998). The Complete German Commission E MonographsTherapeutic Guide to Herbal Medicines, American Botanical Council, Integrative Medicine Communications, Austin, TX/Boston, MA, USA.

Bremner, J. M. (1965). "Total nitrogen," in: Methods of Soil Analysis Part 2. Chemical and Microbiological Properties, C. A. Black (ed.), American Society of Agronomy Journal Incorporated Publications, Madison, WI, USA, pp. 1149-1178.

Çağlar, K. Ö. (1949). Toprak Bilgisi [Soil Science], Ankara Üniversitesi Yayınları, Ankara Turkey.

Çepel, N. (1960). Toprak Türü ve Bunun Arazide El Muayenesi Ille Tayini [Soil Type and its Determination by Hand Inspection in the Field], İstanbul Üniversitesi Yayınları, İstanbul Turkey.

Çepel, N. (1988a). Orman Ekolojisi [Forest Ecology], İstanbul Üniversitesi Yayınları İstanbul, Turkey.

Çepel, N. (1988b). Toprak İlmi [Soil Science], İstanbul Üniversitesi Yayınları, İstanbul, Turkey.

Davis, P. H. (1967). Flora of Turkey and the East Aegean Islands, Vol. II, Edinburgh University Press, Edinburgh, Scotland.

Dirik, H. G. (2008). Bitkilendirme ve Dikim Teknikleri [Planting and Plantation Technics], İstanbul Üniversitesi Yayınları, İstanbul, Turkey.

Dmuchowski, W., Baczewska, A. H., Gozdowski, D., and Bragoszewska, P. (2013). "Effect of salt stress on the chemical composition of leaves of different tree species in urban environment," Fresenius Environmental Bulletin 22(4), 987-994.

Draaijers, G. P. J., Ivens, W. P. M. F., and Bleuten, W. (1988). "Atmospheric deposition in forested gas measured by monitoring canopy throughfall," Water, Air, and Soil Pollution 42(1-2), 129-136.

Elibüyük, M., and Y1lmaz, E. (2010). "Altitude steps and slope groups of Turkey in comparison with geographical regions and sub-regions," Journal of Geographical Sciences 8(1), 27-55.

Eltan, C. (2012). Ihlamur Restorasyon Calışma Raporu [Tilia Restoration Study Report], Bursa Orman Bölge Müdürlügü [Bursa Regional Directorate of Forestry], Bursa. Turkey.

Erşahin, S., Öztaş, T., Namlı, A., and Karahan, G. (2015). Toprak Amenajmanı [Soil Management], Ilksan Matbaası Ltd., Şti., Ankara, Turkey.

European Medicines Agency (EMA) EMA/HMPC/337067/2011 (2012). "Directive 2001/83/EC amended, assessment report on Tilia cordata Miller, Tilia platyphyllos Scop., Tilia $x$ vulgaris Heyne or their mixtures," European Medicines Agency, London, UK.

Evliya, H. (1964). Kültür Bitkilerinin Beslenmesi [Nutrition of Cultural Plants], Ankara Üniversitesi Yayınları, Ankara, Turkey.

Gustafsson, M. E. R., and Franzen, L. G. (2000). "Inland transport of marine aerosols in southern Sweden," Atmospheric Environment 34(2), 313-325.

Gülçur, F. (1974). Toprağın Fiziksel ve Kimyasal Analiz Metodları [Physical and Chemical Analysis Methods of Soil], Kutulmuş Matbaası, İstanbul, Turkey.

Güner, A., Aslan, S., Ekim, T., Vural, M., and Babaç, M. T. (2012). Türkiye Bitkileri Listesi (Damarlı Bitkiler) [Turkey Plants List (Vascular Plants)], Nezahat Gökyiğit Botanik Bahçesi ve Flora Araştırmaları Derneği Yayınları [Nezahat Gökyiğit Botanical Garden and Flora Research Association Publications], İstanbul, Turkey. 
Haralamb, A. T. (1967). Cultura Speciilor Forestiere, Editura Agro-Silvica, Bucuresti, Romania.

Jackson, M. L. (1962). Soil Chemical Analysis, Prentice Hall Inc., Upper Saddle River, NJ, USA.

Jaworski, A. (1995). Silviculture Characteristic of Forest Trees, Gutenberg, Krakow, Poland.

Kalmukov, K. (1984). "The occurrence of Tilia argentea (D.C) in Northeastern Bulgaria,” in: Balkancka Nautsna Konferencia Sofia, Sofia, Bulgaria, pp. 224-231.

Kalmukov, K. (1994). "Studies on eco- and biotype- diversity of Tilia tomentosa Moench. in Northern Bulgaria," in: Proceedings of the Jubilee Symposium, 100 Years Birthday of the Academician Boris Stefanov, vol. 1, Sofia, Bulgaria, pp. 82-85.

Kantarc1, M. D. (1987). Toprak İlmi [Soil Science], İstanbul Üniversitesi Yayınları, İstanbul, Turkey.

Kantarc1, M. D. (2000). Toprak İlmi [Soil Science], İstanbul Üniversitesi Yayınlar1, İstanbul, Turkey.

Karaöz, Ö. (1989). Toprak İmi [Soil Science], Istanbul Üniversitesi Yayınları, İstanbul, Turkey.

Korkut, S. (2011). "Physical and mechanical properties and the use of lesser-known native Silver Lime (Tilia argentea Desf.) wood from Western Turkey," African Journal of Biotechnology 10(76), 17458-17465.

Kroetsch, D., and Wang, C. (2008). "Particle size distribution, in section VI soil physical analysis," in: Soil Sampling and Methods of Analysis, CRC Press, Boca Raton, FL, USA, pp. 713-727.

Leifeld, J., Zimmermann, M., Fuhrer, J., (2008). "Simulating decomposition of labile soil organic carbon: Effects of pH," Soil Biology \& Biochemistry 40, 2948-2951.

Mauer, W. D., and Tabel, U. (1995). "A methodological study to improve the isoenzyme analysis for identification of clones of Tilia (Lindensyn. lime tree)," Silvae Genetica 45(5-6), 351-356.

General Directorate of Forestry (OGM) (2013). "Forest atlas," OGM, (https://www.ogm.gov.tr/ekutuphane/Yayinlar/Orman\%20Atlasi.pdf), Accessed 9 Aug 2019.

OGM (2018). "Forest statistics 2018," OGM, (https://www.ogm.gov.tr/lang/en/Pages/Forests/StatisticalInfo.aspx), Accessed 9 Aug 2019.

Oral, D. (2018). “Tilia L.," in: Türkiye’nin Doğal-Ekzotik Ağaç ve Çalıları [Natural Exotic Trees and Shrubs of Turkey], Ü. Akkemik (ed.), Orman Genel Müdürlüğü Yayınları Ankara [General Directorate of Forestry Publications Ankara], Ankara, Turkey, pp. 415-417.

Öner, H. (2009). Kapıdă̆ Yarımadası Vejetasyonunun Araştırılması [Investigation of Vegetation of Kapidag Peninsula], Ph.D. Thesis, Ege Üniversitesi Fen Bilimleri Enstitüsü [Ege University Graduate School of Natural and Applied Sciences], Bornova-İzmir, Turkey.

Öner, H. H., and Akbin, G. (2010). Kapıdă̆ Yarımadası'nın Fitososyolojik ve Fitoekolojik Yönden Incelenmesi [Investigation of Phyto-ecological and Phytosociological of the Kapıdağ Peninsula] (Report No. 46), Ege Ormancilık Araştırma Enstitüsü [Aegean Forestry Research Institute], İzmir, Turkey.

Özel, N., Öner, H., Akbin, G., Altun, N., and Özkan, K. (2017). Karadă̆ (BursaBalıkesir) Bitki Toplumlarının Belirlenmesi [Identification of Plant Communities in 
Karadă̆ (Bursa-Balıkesir)], (Unpublished Project Report), Ege Ormanc1lık Araştırma Enstitüsü [Aegean Forestry Research Institute], İzmir, Turkey.

Özyuvac1, N. (1999). Meteoroloji ve Klimatoloji [Meteorology and Climatology], İstanbul Üniversity Yayınları, İstanbul, Turkey.

Radoglou, K., Dobrowolska, D., Spyroglou, G., and Nicolescu, V. N. (2009). “A review on the ecology and silviculture of limes (Tilia cordata Mill., Tilia platyphyllos Scop. and Tilia tomentosa Moench.) in Europe," Bodenkultur 3(3), 9-20.

Reinap, A., Wiman Bo, L. B., Svenningsson, B., and Gunnarsson, S. (2012). "Forestedge effects on sea-salt aerosol deposition: A wind-tunnel study using living oak leaves," Boreal Environment Research 17, 193-209.

Richards, L. A. (1954). Diagnosis and Improvement of Saline and Alkali Soils, U.S. Department of Agriculture, Washington DC, USA.

Saatçı, F., Tuncay, H., Altınbaş, Ü., and Akıncı, M. Ç. (1983). Toprak ve su Analiz Yöntemleri [Soil and Water Analysis Methods], Ege Üniversitesi Ziraat Fakültesi Yayınları [Ege University Graduate School of Natural and Applied Sciences], Bornova, İzmir, Turkey.

Şahin, N., Özdemir, M., Tandoğan, M., Sezgin, G., Arslan, A., Sezik, E., Yeşilada, E., and Güzelmeriç, E. (2018). Marmara Bölgesinde Gümüşi Ihlamurun (Tilia tomentosa Moench) Çiçek Kalitesi Üzerine Araştırmalar [Investigations on the Quality of Flowers in the Marmara Region (Tilia tomentosa Moench)], (Unpublished Project Report), Marmara Ormancılık Araştırma Enstitüsü [Marmara Forestry Research Institute], İstanbul, Turkey.

Saltalı, K. (2014). Toprak Verimliliğinde Organik Maddenin Önemi [Importance of Organic Matter in Soil Fertility], Kahramanmaraş Sütçü İmam Üniversitesi Yayınları [Kahramanmaraş Sütçü İmam University Publications], Kahramanmaras, Turkey.

Stanescu, V., Sofletea, N., and Popescu, O. (1997). Flora Forestiera lemnoasa a Romaniei [Woody Forest Flora of Romania], Editura Ceres, Bucuresti, Romania.

Tan, A. (2010). Türkiye Gıda ve Tarım Bitki Genetik Kaynaklarının Durumu Gıda ve Tarım İçin Bitki Kaynaklarının Muhafazası ve Sürdürülebilir Kullanımına İlişkin Türkiye İkinci Ülke Raporu [Turkey Food and Agriculture Plant Status of Food Storage and Turkey and the Second National Report on the Sustainable Use of Plant Genetic Resources for Agricultural Resources], ETAE Yayınlar1 [Aegean Agricultural Research Institute Publishing], Bornova, İzmir, Turkey.

Thorntwaite, C. W. (1948). "An approach to a rational classification of climate," Geographical Review 38(1), 55- 94.

Tuttu, G., Ursavaş, S., and Söyler, R. (2017). "Harvest yields and ethnobotanical use of linden flowers in Turkey," Journal of Anatolian Forest Research 3(1), 60-66.

Tüzüner, A. (1990). Toprak ve Su Analiz Laboratuvarları El Kitabı [Handbook of Soil and Water Analysis Laboratories], Tarım Orman ve Köyişleri Bakanlığı Köy Hizmetleri Genel Müdürlügü yayınları [Ministry of Agriculture, Forestry and Rural Affairs General Directorate of Rural Services], Ankara, Turkey.

Uslu, J. (2004). Ihlamur Sektörü Raporu [Lime Tree Sector Profile Report], Istanbul Ticaret Odası [Istanbul Chamber of Commerce], İstanbul, Turkey.

Ürgenç, S., and Çepel, N. (2001). A ğaçlandırma Için Tür Seçimi, Tohum Ekimi ve Fidan Dikiminin Pratik Esaslarl [Selection of Species for Afforestation, Seed Cultivation and Practical Principles of Planting Seedlings], Tema Yayınlar1 [Theme Publications], İstanbul, Turkey. 
Verhoeven, B. (1980). Salty Soils. Drainage Principles and Applications. 1. Introductory Subjects, International Institute for Land Reclamation and Improvement (ILRI), Publication, Pudoc Scientific Publishers, Wageningen, Netherlands.

Wuyts, K., Verheyen, K., Schrijver, A. D., Cornelis, W. M., and Gabriels, D. (2008). "The impact of forest edge structure on longitudinal patterns of deposition, wind speed, and turbulence," Atmospheric Environment 42(37), 8651-8660.

Xie, C. (2018). "Tree diversity in urban parks of Dublin, Ireland," Fresenius Environmental Bulletin 27(12A), 8695-8708.

Article submitted: July 18, 2019; Peer review completed: October 10, 2016; Revised version received and accepted: October 15, 2019; Published: October 21, 2019.

DOI: 10.15376/biores.14.4.9588-9600 